\title{
Frustrated Achievers or Satisfied Losers? Inter- and Intragenerational Social Mobility and Happiness in China
}

\author{
Emma Zang, ${ }^{a}$ Nan Dirk de Graaf ${ }^{b}$
}

a) Duke University; b) University of Oxford

\begin{abstract}
How and to what extent is rank mobility associated with happiness of the Chinese population? Does mobility provide insight into the vast numbers of frustrated workers in times of economic growth? To date, few studies have examined the consequences of social mobility on happiness in transitional societies. The present analysis investigates the association of both inter- and intragenerational rank mobility with happiness in China using data from the General Social Survey's 2003, 2006, and 2008 waves. We examine two general mechanisms, social adaptation and social comparison, by statistically decomposing the independent contributions of social origin, social destination, and mobility. We find there is a significant positive association between short-distance intragenerational downward mobility and happiness, while not any intergenerational mobility pattern has been found to be significant. Apparently, we have a group of satisfied losers. Our findings favor social comparison explanations.
\end{abstract}

Keywords: inter- and intragenerational social mobility; happiness; frustrated achievers; transitional societies

W HILE debates on whether rising income increases people's happiness are long-lasting, the relationship between general social status improvement and happiness has been neglected in the field of happiness research. Since the Easterlin paradox in 1974, the relationship between income and happiness has generated a hot debate in economics, sociology, and psychology. From the income and happiness literature, consistent evidence has shown that happiness is strongly affected by relative social status (Dorn et al. 2007; Ferrer-i-Carbonell 2005; Luttmer 2005). The reference level to which people compare their own social status can be not only the social status of some relevant others but also the social status that the individuals themselves had earned (Clark and D'Angelo 2009). The latter is often called inter- or intragenerational social mobility in sociology. However, most studies considering comparisons with relevant others did not consider comparisons with themselves in the past.

Meanwhile, few studies examining the effect of inter- or intragenerational social mobility have considered the aspect of social comparison with some relevant others. Most of these studies measure social mobility using changes in absolute occupation, education, or income. However, even if an individual has experienced upward mobility measured by those changes, his or her position in society may still be relatively lower than before because other people have had greater magnitudes of improvement. In most cases, social scientists are interested in social mobility as a change in social status relative to others' social status within a given society, 
independent of economic growth. Ignoring the social comparison effect may lead us to identify a different association with social mobility, rather than the one of our interest.

In recent studies, upwardly mobile respondents in some transitional societies such as Russia and Peru have reported more frustration and lower subjective wellbeing than those who are not upwardly mobile. This group of people has been referred to as "frustrated achievers" (Brockmann et al. 2009; Graham 2003). This phenomenon has called increasing attention, and scholars tend to make explanations based on the features of transitional societies. It is hypothesized that some people living in transitional societies have experienced large income gains in absolute terms, while their relative income positions have gotten worse (Graham and Pettinato 2002; Ravallion and Chen 2007; Sanfey and Teksoz 2007). On average, these frustrated achievers have been found to be those who started from a below average social origin and ended up at or above average income in urban areas (Graham 2003).

However, a lot of questions regarding the "frustrated achievers" phenomenon in transitional societies remain unresolved. First, does the "frustrated achievers" phenomenon exist in other transitional societies other than those being studied in previous research? Second, most of previous studies have only focused on income mobility. Does the same phenomenon and explanations apply to social mobility in social status in general? Third, besides the social comparison hypothesis, does another widely examined hypothesis in happiness studies-social adaptationapply to the phenomenon?

Studying transitional societies makes it possible to address unresolved questions in the literature of the relationship between social mobility and happiness. As we will show in the literature review section later, most previous studies on social mobility and individual happiness focus on developed countries, and their findings are not all consistent. Studying transitional societies may contribute to the literature in two aspects. First, some already identified determinants of individual happiness, such as inequality, social security, and individual social status, may fluctuate more in transitional societies than in developed societies (Graham and Pettinato 2002). As a result, individual social mobility experiences and perceived social mobility experiences can be very different for people in transitional societies, which may have new implications on happiness. Second, besides those already identified determinants of individual happiness, there are some potential determinants that are, to some extent, unique to transitional societies. Examples of these factors are globalization and inequality driven by technology-led growth (Graham and Pettinato 2002). These unique potential determinants may add new knowledge to our understanding of the relationship between social mobility and happiness.

As one of the largest transitional societies in the world, the paradox of economic growth and dissatisfaction makes China an especially interesting case to study the relationship between social mobility and happiness. In China, rapid economic growth intensifies people's dissatisfaction and relative deprivation, known as the "China puzzle" (Brockmann et al. 2009). However, few studies have examined the "China puzzle" using individual-level data; that is, does individual inter- and intragenerational social mobility lower individual happiness? 
This study intends to answer this question by exploring the relation with interand intragenerational social mobility on happiness in China using the General Social Survey's 2003, 2006, and 2008 waves. We examine whether inter- and intragenerational rank mobility is related to individual happiness, and if so, whether there is a phenomenon of "frustrated achievers." Drawing from previous literature, we focus on examining two popular hypotheses: social adaptation and social comparison. Sex difference, which is not examined in some previous intragenerational mobility studies because of data availability, is also examined in the current study.

Social mobility, in the present article, is based on relative position changes in the distribution of social attainments rather than their absolute improvement. Studying rank mobility (that is, change of an individual's relative position in the society he or she belongs to) is a way to consider both aspects of relative social status (i.e., comparison with relevant others and comparison with old status). Moreover, because occupational structures vary by country, the measure of rank mobility also makes it easier to compare our results with those in other countries to investigate cross-national differences in the association between social mobility and happiness.

This study intends to contribute to the literature in four ways. First, studying China, one of the largest transitional societies nowadays, will facilitate our fundamental understanding of the relationship between social mobility and happiness. To our knowledge, it is the first study to explore the association with both intraand intergenerational social mobility on happiness in China. Our findings will add new evidence to the literature of social mobility and happiness in transitional societies, and more importantly, more evidence in transitional societies helps us answer unsolved questions in the literature of the relationship between social mobility and happiness in general in the two ways mentioned above. Second, rather than just examining inter- or intragenerational mobility as most previous studies did, by considering both inter- and intragenerational mobility, we are able to examine whether the associations with happiness differ. Some argue that intergenerational social mobility means leaving the family ties and thus will have a stronger association than intragenerational mobility (Hadjar and Samuel 2015). Third, this study investigates the relation of inter- and intragenerational mobility with happiness for both males and females using a nationally representative sample that includes both urban and rural respondents. Prior studies have mainly focused on males and urban residents, whereas the patterns for females and rural residents are studied less. Fourth, this study considers both comparison with relevant others and comparison with people's past using rank mobility, while previous studies only took one of them into account.

The article is organized as follows. We first present a conceptual framework and hypotheses. Next, we describe the analytical strategy, followed by a description of the data and empirical results. We conclude with a discussion of the main findings and possible limitations of this study.

\section{Theoretical Framework and Hypotheses}

We consider four combinations of social mobility and happiness: satisfied achievers (happy and upwardly mobile), satisfied losers (happy and downwardly mobile), 
frustrated achievers (unhappy and upwardly mobile), and frustrated losers (unhappy and downwardly mobile) (Becchetti and Rossetti 2009). Two hypotheses are considered in the present study: social adaptation and social comparison. Next, we will discuss the power of each hypothesis in explaining each of the four possible outcomes.

\section{Social Adaptation}

Many studies on the consequence of mobility are sparked by Sorokin (1962) and other theories in the Durkheimian tradition. These theories propose that social mobility results in identity conflict and subjective feelings of deprivation (Durkheim 1951 [1897]). Regardless of whether it is upward or downward, social mobility is expected to cause alienation and abnormal strain, which may be manifested in dissatisfaction with life.

Another extended version of this theory predicts that only downward mobility is detrimental to mental health (Newman 1988), whereas positive events or voluntary upward mobility has little impact on mental health (e.g., Wheaton 1990; Thoits 1983). According to this theory, downwardly mobile people suffer from stress of failures and adaptation problems because of involuntary losses of achieved status. Lowered social position after the downward mobility is not the cause of lowered happiness level, but the free fall itself is (Houle 2011). These hypotheses view upward mobility as a positive life event that people normally enter into by choice, thus it should have little effect on subjective well-being. For example, some studies find that job promotion produced no influence on mental health, probably because job promotions are so prevalent and sometimes promotions do not depend on individual performance (Wheaton 1990).

Most early studies in the United States and some European countries find no statistically significant results for these hypotheses in terms of either intergenerational mobility or intragenerational mobility (Marshall and Firth 1999; Houle and Martin 2011; Houle 2011). There are some exceptions: Hadjar and Samuel (2015) find a negative association between intergenerational upward mobility and happiness in a UK sample, while there is no such effect in a Swiss sample; for intragenerational mobility, no effects are found for either of the two countries.

Despite all these findings in developed countries, our knowledge of whether general social status improvement has an impact on individual happiness in the context of transitional societies is still very limited. Although recent studies on income and happiness in transitional societies show that people report lower subjective well-being while their income has grown, few studies have considered the relationship between general social status improvement and happiness. Furthermore, most previous studies on "frustrated achievers" have ignored the possibility of the adaptation hypothesis.

There are several reasons to expect adaptation to a new social class or status might be a cause of dissatisfaction in transitional societies rather than in developed countries. One of the unique features of transitional societies vis-à-vis nontransitional societies is rapid change. In a transitional economy like China, societal systematic social mobility driven by economic reforms and social change is not 
uncommon. For instance, during the market reform in the late twentieth century, a large number of employees working in the state-owned enterprises lost their stable lifetime jobs and the related social welfare, including medical benefits, housing, and education (Tang and Parish 2000). This kind of downward mobility is sudden and uncontrollable for most people. It is likely to generate life dissatisfaction for these downwardly mobile people, who are "frustrated losers."

Besides downward mobility, people who have experienced upward mobility are likely to suffer from adaptation problems in transitional societies. Large-scale migration from rural areas to urban areas and from small towns to large cities made upward mobility possible for a lot of people. Although the living standards of those immigrants have been improved to be comparable to those of natives, a substantial amount of literature has provided evidence that the overall level of social inclusion of those immigrants is still very low (Zhang and Lei 2008). It is likely to generate life dissatisfaction for these upwardly mobile people, who are "frustrated achievers."

We therefore expect that in China, both upward and downward mobility will cause adaptation problems and hence lower people's happiness. Even if upward mobility has little impact, as some hypotheses suggested, in total we would expect mobile individuals to be less happy than those nonmobile ones. In general, women are found to be more likely than men to have depression and report stress (NolenHoeksema 2001), suggesting that women are even less capable of adapting to new environments than men. All of the above lead to the following hypotheses:

- Hypothesis 1a: The happiness level of mobile individuals in China will be lower than their nonmobile counterparts.

- Hypothesis 1b: Downward mobility lowers individuals' happiness.

- Hypothesis 1c: The longer the mobility distance, the larger the negative impact on happiness because of increasing difficulties of adaptation.

- Hypothesis 1d: Women's happiness levels are more affected by their social destinations compared with men.

\section{Social Comparison}

The social comparison hypothesis has been widely preferred among the income mobility and happiness studies (e.g., Brockmann et al. 2009; Graham and Pettinato 2002). Consistent with the Easterlin argument, happiness will not be boosted with the increase of income in the case of unchanged relative income. Being more successful than relevant others improves happiness through gaining a positive self-evaluation, while being less successful than relevant others lowers happiness (Samuel, Bergman, and Hupka-Brunner 2013; Festinger 1954). "Frustrated achievers" are likely to compare their situation negatively to relevant others because their relative position might have declined. Even if people are in an affluent situation, when they compare themselves with people in even better conditions, they will be unhappy. Similarly, people in adverse conditions will feel happier when they compare themselves with those in worse conditions, known as the "satisfied losers." 
The social comparison hypothesis suggests that as the economy grew in such transitional societies as Peru and Russia, the income distribution within the societies skewed towards the upper-income groups (Graham and Pettinato 2002). Inequality in the income distribution became more crystalized. Even though people's objective quality of life improves, high inequality makes them compare themselves with relevant others negatively, which leads to lower levels of happiness. The implication is that only if people are upwardly mobile to the highest status category will they potentially be happier. Furthermore, if mobile Chinese compare with others who are mobile, it might be that the more one is upwardly or downwardly mobile, the more or less happy one becomes.

There are several reasons to expect social comparison might cause the "frustrated achievers" phenomenon in China. A few years after the establishment of the new China in 1949, China initiated its first five-year plan (1952-1956) in order to realize rapid industrialization. Many new work places (i.e., danwei) were built with strict state control. While before 1950, most work took place in households or in enterprises that were essentially extensions of the households, the transition to socialism in the 1950s transformed China's working population into wage earners. Danwei were responsible for many key events in the lives of their members and could be seen as an important extended family network of contemporary Chinese society. Inequality within danwei was very low (Zhou 2000). So, when people compared themselves with relevant others-most of whom were colleagues in the same danwei-they would not rate themselves negatively. Inequality has increased dramatically since China reformed its economy in 1978. China's Gini coefficient was 0.30 in 1980, while it grew to the range of $0.53-0.55$ in the recent decade (Xie and Zhou 2014). The danwei system has lost its importance. When people compare themselves with the winners in the skewed resource distribution, relative deprivation rises (Brockmann et al. 2009). This suggests that even those upwardly mobile to the highest 25 percent status category will compare themselves with the highest one or two percent and will therefore still be unhappy.

Women have been found to be equally satisfied when they earn less than men, which is known as the paradox of the contented working woman (e.g., Schreiber 1979; Weaver 1978). Social comparison or relative deprivation theory provides a plausible explanation that women may be content because they do not perceive a discrepancy between the pay they want and the pay they receive (Jackson 1989). This suggests that social comparison may be more severe among men than among women. All above lead to the following hypotheses:

- Hypothesis 2a: The happiness level of upwardly mobile individuals in China will only be higher if they reach the highest status group. In our case, the highest status group means the top twenty-fifth percentile.

- Hypothesis $2 \mathrm{~b}$ : Because hardly anyone will reach the elite status category, the upwardly mobile will not be happier. This hypothesis assumes that upwardly mobile people only compare themselves with the top one or two percent.

- Hypothesis 2c: The more an individual is upwardly or downwardly mobile, the larger the positive or negative impact on happiness. This hypothesis assumes people compare mobility distance with others. 
- Hypothesis 2d: Women's happiness levels are less affected by their social destinations compared with men.

\section{Data}

Our analysis is based on cross-sectional data pooled from the China General Social Survey's 2003, 2006, and 2008 waves. Other waves are not included because they don't have all the variables we need. The China General Social Survey is conducted by the Sociology Department at the Renmin University of China and the Social Science Department at the Hong Kong University of Science and Technology. It adopts a hierarchical design and multistage probability proportional to size (PPS) random sampling. The survey includes individuals aged 18 or over in both rural and urban areas. It spans across most provinces or municipalities as well as autonomous regions in China. ${ }^{1}$ In 2003, a total of 5,900 respondents from 125 villages and 559 communities were interviewed, with 5,894 valid responses obtained. In 2006, it contains a national random sample of 10,151 members of the population aged 18-70 in China, with 6,013 interviewed in urban areas and 4,138 interviewed in rural areas. The 2008 wave covers about 3,982 urban households and 2,018 rural households. These datasets contain retrospective data giving the occupational history of each individual in the sample, which allows us to link an individual's occupational changes to his or her reported happiness. More details of each wave and further information on the sampling procedures are documented in Bian and $\mathrm{Li}$ (2012).

Our sample is limited to respondents older than age 30 in order to eliminate the possibility that individuals' social destinations are automatically close or similar to their social origins just because they happen to be young (e.g., time is needed for social mobility to occur). In addition, after this data restriction, current social status is likely to be measured when respondents had reached their peak occupational attainment. We also remove individuals who have never worked. After these selections, 16,936 valid cases remain.

Father's statuses and respondents' prior and current statuses are missing in about 24 percent, 16 percent, and 14 percent of the observations, respectively. We use multiple imputations to replace missing data so that the final analytical sample retains all 16,936 eligible respondents. The multiple imputation method is advantageous over other methods in dealing with missing data by providing unbiased estimates for standard errors (Acock 2005). It replaces missing values with predictions based on information observed in the sample and accounts for random uncertainty across each imputed dataset (Acock 2005; Rubin 1987). Prediction models are based on data from the original dataset, consisting entirely of individuals aged 18 and over. We imputed 10 data sets using the "ice" command (Royston 2004) in STATA 11, estimating regression coefficients in bootstrap samples. Then we used the "mim" command (Carlin, Galati, and Royston 2008) to obtain estimates that appropriately combine the information from all 10. A description of all the variables before and after imputation can be found in the online supplement. In Table 1, we only show selected key variables. 
Table 1: Variable descriptive statistics.

\begin{tabular}{lcc}
\hline & $\begin{array}{c}\text { Before imputation } \\
\text { Mean }\end{array}$ & $\begin{array}{c}\text { After imputation } \\
\text { Mean }\end{array}$ \\
\hline Happiness & 0.456 & 0.471 \\
Father's class & & \\
Lower status & 0.473 & 0.422 \\
Lower-middle status & 0.024 & 0.112 \\
Higher-middle status & 0.260 & 0.228 \\
Higher status & 0.244 & 0.238 \\
& & \\
Prior class & & 0.315 \\
Lower status & 0.355 & 0.195 \\
Lower-middle status & 0.175 & 0.265 \\
Higher-middle status & 0.253 & 0.224 \\
Higher status & 0.217 & \\
Current class & & 0.285 \\
Lower status & & 0.215 \\
Lower-middle status & 0.285 & 0.268 \\
Higher-middle status & 0.217 & 0.231 \\
Higher status & 0.268 & \\
\hline
\end{tabular}

Source: China General Social Survey 2003, 2006, 2008.

\section{Measurement}

General happiness is the most common measure of subjective well-being. Previous research defines subjective well-being as a global judgment concerning the overall quality of one's present life (Diener 1984). In our dataset, happiness is measured based on the answers to the question, "Are you happy with your life?" where the choices are (1) "Very unhappy," (2) "Unhappy," (3) "So so," (4) "Happy," and (5) "Very happy." We further combine "Very unhappy," "Unhappy," and "So so" into "Unhappy" as well as "Happy" and "Very happy" into "Happy" in order to get a dichotomous variable structure. We are choosing the dummy variable representation because most people have reported "So so," "Happy," or "Very happy" in the data, which makes the distribution of the five categories skewed. Although by making a dummy variable out of the five-scaled happiness variable may lead to some loss of information, we believe it will give us a more explicit result.

Intragenerational social mobility is measured through intragenerational changes in professional status, with prior status measured according to the International Socio-Economic Index (ISEI) (Ganzeboom, De Graaf, and Treiman 1992) quartile of the respondent's first job and current status measured according to respondent's current or last ISEI quartile. We first divide respondents' prior and current ISEI scores 
Table 2: Mean happiness levels by prior and current social status.

\begin{tabular}{lccccc}
\hline & \multicolumn{5}{c}{ Prior Class } \\
& $\begin{array}{c}\text { Lower } \\
\text { status }\end{array}$ & $\begin{array}{c}\text { Lower-middle } \\
\text { status }\end{array}$ & $\begin{array}{c}\text { Higher-middle } \\
\text { status }\end{array}$ & $\begin{array}{c}\text { Higher } \\
\text { status }\end{array}$ & $\begin{array}{c}\text { Column } \\
\text { means }\end{array}$ \\
Lower status & 0.404 & 0.480 & 0.486 & 0.498 & 0.429 \\
& $(0.217)$ & $(0.037)$ & $(0.024)$ & $(0.007)$ & $(0.286)$ \\
Lower-middle status & 0.419 & 0.407 & 0.455 & 0.488 & 0.432 \\
Higher-middle status & $(0.066)$ & $(0.074)$ & $(0.092)$ & $(0.014)$ & $(0.214)$ \\
& 0.435 & 0.439 & 0.431 & 0.489 & 0.444 \\
Higher status & $(0.056)$ & $(0.028)$ & $(0.127)$ & $(0.046)$ & $(0.268)$ \\
& 0.528 & 0.554 & 0.582 & 0.606 & 0.589 \\
Row means & $(0.036)$ & $(0.017)$ & $(0.043)$ & $(0.143)$ & $(0.231)$ \\
& 0.421 & 0.449 & 0.464 & 0.566 & \\
\hline
\end{tabular}

Numbers in parentheses indicate mean proportions of respondents in each cell of the mobility table. $\mathrm{N}=16,936$.

Source: China General Social Survey 2003, 2006, 2008.

into quartiles, respectively. The first quartile is defined as lower status, the second and the third quartile as lower-middle status and higher-middle status, respectively, and the last quartile as higher status. Thus, a four-category structure is established for both prior status and current status. ${ }^{2}$

Based on the prior and current status position, a $4 \times 4$ table with 16 categories of social mobility (see Table 2) is constructed, showing three dimensions of social mobility. The first dimension indicates whether mobility occurred. Cells on the main diagonal represent immobility, whereas nondiagonal cells indicate the occurrence of social mobility. The second dimension is the direction of social mobility. Cells below the diagonal represent upward mobility, whereas cells above the diagonal represent downward mobility. The third dimension is the distance of social mobility. We measure mobility distance by taking the direction and number of gradients between prior status and current status. Among all respondents, 23.2 percent are downwardly mobile, 21.5 percent are upwardly mobile, and 44.6 percent are mobile. 12.1 percent had one-step upward mobility, 6.8 percent had two-step upward mobility, and 2.6 percent had three-step upward mobility. 18.3 percent had one-step downward mobility, 3.9 percent had two-step downward mobility, and 0.9 percent had threestep downward mobility.

Similarly, intergenerational social mobility is measured through intergenerational changes in professional status, with father's status measured according to the International Socio-Economic Index (Ganzeboom et al. 1992) quartile of the father's socioeconomic status when the respondent was young ${ }^{3}$ and current status measured according to respondent's current or last ISEI quartile. Based on the father's and current status, a similar $4 \times 4$ table with 16 categories of social mobility (see Table 3 ) 
Table 3: Mean happiness levels by father's and current social status.

\begin{tabular}{lccccc}
\hline & \multicolumn{5}{c}{ Father's Class } \\
& $\begin{array}{c}\text { Lower } \\
\text { status }\end{array}$ & $\begin{array}{c}\text { Lower-middle } \\
\text { status }\end{array}$ & $\begin{array}{c}\text { Higher-middle } \\
\text { status }\end{array}$ & $\begin{array}{c}\text { Higher } \\
\text { status }\end{array}$ & $\begin{array}{c}\text { Column } \\
\text { means }\end{array}$ \\
Respondent's Class & 0.398 & 0.457 & 0.485 & 0.512 & 0.429 \\
Lower status & $(0.276)$ & $(0.011)$ & $(0.03)$ & $(0.028)$ & $(0.286)$ \\
& 0.392 & 0.483 & 0.417 & 0.480 & 0.432 \\
Lower-middle status & $(0.144)$ & $(0.016)$ & $(0.067)$ & $(0.053)$ & $(0.214)$ \\
& 0.420 & 0.478 & 0.432 & 0.477 & 0.444 \\
Higher-middle status & $(0.148)$ & $(0.013)$ & $(0.064)$ & $(0.061)$ & $(0.268)$ \\
& 0.554 & 0.568 & 0.595 & 0.617 & 0.589 \\
Higher status & $(0.123)$ & $(0.012)$ & $(0.051)$ & $(0.09)$ & $(0.231)$ \\
& 0.427 & 0.494 & 0.474 & 0.534 & \\
Row means & $(0.422)$ & $(0.112)$ & $(0.228)$ & $(0.238)$ & \\
\hline
\end{tabular}

Numbers in parentheses indicate mean proportions of respondents in each cell of the mobility table. $\mathrm{N}=16,936$.

Source: China General Social Survey 2003, 2006, 2008.

is constructed. Among all respondents, 27.8 percent are downwardly mobile, 34.2 percent are upwardly mobile and 62 percent are mobile. 15.6 percent had one-step upward mobility, 11.9percent had two-step upward mobility, and 6.7percent had three-step upward mobility. 15.9 percent had one-step downward mobility, 8.6 percent had two-step downward mobility, and 3.3 percent had three-step downward mobility.

The use of the socioeconomic index has advantages over the widely employed Erikson-Goldthorpe-Portocarero (EGP) class schema (Erikson, Goldthorpe, and Portocarero 1979) in this context. First, the EGP schema is not considered to be strictly hierarchical, and therefore it is hard to define upward or downward mobility. Our measurement, on the other hand, is directly comparable. Second, using social status quartiles is a natural and direct way to measure individuals' or their fathers' positions in the society in their or their fathers' generations, which depends not only on their own occupation, education, and income, etc. but also on the distribution of attainments in the society they belong to. Rather than absolute mobility, we measure relative mobility. According to our measurement, mobility in rank occurs when an individual's position in the distribution changes without the necessity of any change in his or her occupation, education, or income. That is, upward mobility measured by EGP class schema may coexist with downward mobility in rank measured in this study.

Although the association between social mobility and happiness is the primary focus of the current work, other relevant variables that are likely to affect the relationship between happiness and social mobility are also considered. These variables include sex, age, current location (rural or urban), ethnicity, political status, 
marital status, and how long they have been at the social destination. Among the variables included, female, married, Han ethnicity, rural, and communist party member are directly determined based on the information provided by respondents' answers. Age is coded as the survey year minus the birth year. Time at destination is measured by the difference between the survey year and the year a respondent started his or her current job. ${ }^{4}$ Then, we created a dummy variable indicating whether the respondent stayed at the current status for a period of time longer than the median.

\section{Empirical Strategy}

Most past research on mobility is unable to disentangle the association contributed by mobility from the association contributed by current social status. For instance, traditional square (Duncan 1966) and diamond additive models (Hope 1975) fail to set parameters for the nonmobility effects to permit an assessment of mobility effects independent of status effects (Sobel 1981). These approaches adopt a regression framework that suffers from linear dependence problems (Hendrickx et al. 1993; Hope 1975; Sobel 1981).

The present analysis applies the diagonal mobility models (DMM) proposed by Sobel (1981). This model estimates the contributions of mobility origin and destination using a single vector of coefficients along with a weighting parameter to model the relative importance of mobility origin and destination. The model provides point estimates for the extent to which mobile individuals resemble the nonmobile members of their prior or current social status. The assumption here is that the nonmobile members of a status group are the core of the group (De Graaf, Nieuwbeerta, and Heath 1995). This model offers a parsimonious and appropriate representation of origin, destination, and mobility contributions with fewer degrees of freedom than conventional models and is suitable for modeling these potential mechanisms simultaneously (Hendrickx et al. 1993; Sobel 1981, 1985; Weakliem 1992). The baseline model for a dichotomous dependent variable is given by:

$$
\begin{gathered}
\operatorname{prob}\left(Y_{i j k}=1\right)=1 /\left(1+e^{-l i n}\right) \\
\operatorname{lin}=p m_{i}+(1-p) m_{j} \\
\left(i=1, \ldots, T ; j=1, \ldots, T ; k=1, \ldots, N_{i j} ; p \in[0,1]\right)
\end{gathered}
$$

where $Y_{i j k}$ equals 1 if respondent $k$ in the $i j$ th cell reports happy and 0 if not; $m_{i}$ stands for the expected mean happiness of the stable members of a respondent's prior status; $m_{j}$ stands for the expected mean happiness of the stable members of a respondent's current status; $T$ is the total number of social classes; and $N_{i j}$ is the number of observations in the $i j$ th cell of the mobility table.

The diagonal mobility model has two reference values: namely, the diagonal mean of the origin category $m_{i}$ and that of the destination category $m_{j}$. Thus, $p$ and $(1-p)$ are interpreted as origin and destination weights, respectively. When $p>0.5$, the origin effect is larger than the destination effect. The opposite is true when $p$ $<0.5$. The diagonal mobility model considers the conceptual distinctions between 
origin and destination effects but does not preclude any inferences on the effects of mobility (Sobel 1981). Therefore, the existence of mobility contribution can be determined by adding mobility variables. Covariates may also be added on the basis of the baseline model, and full model is given by:

$$
\begin{gathered}
\operatorname{prob}\left(Y_{i j k}=1\right)=1 /\left(1+e^{-l i n}\right) \\
\operatorname{lin}=p m_{i}+(1-p) m_{j}+\sum \underset{w=1}{\mathrm{~W}} b_{w} M_{w}+\sum_{z=1}^{\mathrm{Z}} b_{z} C_{z} \\
\left(i=1, \ldots, T ; j=1, \ldots, T ; w=1, \ldots, W ; k=1, \ldots, N_{i j} ; \mathrm{z}=1, \ldots, \mathrm{Z} ; p \in[0,1]\right)
\end{gathered}
$$

where $b_{w}$ and $b_{z}$ are interpreted as the parameters of the mobility variables and covariates, respectively; $W$ indicates total number of mobility variables; $Z$ indicates total number of covariares; $M_{w}$ represent mobility variables; and $C_{z}$ represent the covariates. $^{5}$

In order to test the sex disparity hypothesis, we include interaction terms between female and the origin and destination weights. The model is:

$$
\begin{gathered}
\operatorname{prob}\left(Y_{i j k}=1\right)=1 /\left(1+e^{-l i n}\right) \\
\operatorname{lin}=(p+\gamma p \times \mathrm{F}) m_{i}+(1-p-\gamma p \times \mathrm{F}) m_{j}+\sum_{w=1}^{w} b_{w} M_{w}+\sum_{z=1}^{z} b_{z} C_{z} \\
\left(i=1, \ldots, T ; j=1, \ldots, T ; k=1, \ldots, N_{i j} ; p \in[0,1]\right)
\end{gathered}
$$

where $F$ stands for female. The current status weight increases by $\gamma p$ if the individual is a female, and the prior status weight decreases by $\gamma p$ if the individual is a male. For an elaboration on such conditional weight coefficients, see De Graaf (1991).

\section{Results}

\section{Bivariate Patterns}

In the $4 \times 4$ table of intragenerational mobility in Table 2, the proportion of happiness in every cell represents the percentage of respondents feeling happy for different intragenerational mobility types of the population. A relationship clearly exists between respondent's current social status and happiness. The percentage of respondents feeling happy was 42.9 percent for lower status, 43.2 percent for lowermiddle status, 44.4 percent for higher-middle status, and 58.9 percent for higher status. Looking at the diagonal, we notice more variance-i.e., the percentage of happiness was 40.4 percent, 40.7 percent, 43.1 percent, and 60.6 percent for lower status, lowermiddle status, higher-middle status, and higher status, respectively. Similarly, in the $4 \times 4$ table of intergenerational mobility in Table 3, looking at the diagonal, the 
percentage of happiness was 39.8 percent, 48.3 percent, 43.2 percent, and 61.7 percent for lower status, lower-middle status, higher-middle status, and higher status, respectively. Comparing the marginal distribution with the diagonal suggests social mobility may have mixed influences on happiness.

\section{Multivariate Results}

To eliminate the influences of other covariates on the relationship between intragenerational social mobility and happiness, a multivariate statistical analysis is conducted using the logistic diagonal mobility model. Model 1 in Table 4 is a baseline model providing point estimates for the relative importance of prior and current statuses after controlling for various covariates but it does not include any mobility variables. ${ }^{6}$ The results show that respondents' current social statuses are more important than prior social statuses for mobile individuals' happiness ( $p=$ $0.296<0.5)$. Without considering mobility itself, a distinct gradient exists among different statuses. The log odds of being happy are $-0.282,-0.154,-0.008$, and 0.513 for lower status, lower-middle status, higher-middle status and higher status, respectively. This suggests that people with higher relative social status are more likely to be happy. Furthermore, the relative weight of one's prior status is 0.3 versus 0.7 for the current status.

An indicator for being intragenerationally mobile, irrespective of whether it is downward or upward mobility, is included in model 2. Surprisingly, the happiness level of mobile individuals is significantly higher than their nonmobile counterparts, which rejects our hypothesis 1a. In order to explore whether this positive relationship is driven by a subpopulation of the mobile individuals, we have to consider mobility directions and distances. Mobility variables with directions are included in model 3. Only the downward mobility variable is found to have a significant positive relationship with happiness, which does not support our hypothesis $1 \mathrm{~b}$. The result gives us two pieces of important information. First, it indicates that the direction of mobility does matter. Second, the adaptation hypothesis is not a satisfactory explanation because it cannot explain why mobility, especially downward mobility, makes people happier.

After adding variables indicating social mobility distance in model 4, results show that only one-step downward mobility has a significant positive association with happiness. This result supports neither hypothesis 1c nor hypothesis 2c. A closer look at those who have experienced one-step downward mobility revealed that people who are less educated, urban, non-communist party members, and have stayed at the social destination longer are more likely to have experienced one-step downward mobility. These results are obtained from a logistic regression model using one-step downward mobility as the dependent variable, controlling for age, age square, rural location, years of education, communist party membership, average household income, marital status, the Han ethnicity, sex, time at social destination, survey year, and province. In our sample, 41 percent of this group of people were from higher-middle status and ended up at lower-middle status. Considering that our measure of social mobility is social rank mobility, we must be aware that some people would be categorized as having experienced downward 
Table 4: Intragenerational estimates from diagonal mobility models predicting happiness.

\begin{tabular}{|c|c|c|c|c|c|c|}
\hline & Model 1 & Model 2 & Model 3 & Model 4 & Model 5 & Model 6 \\
\hline \multicolumn{7}{|l|}{ Prior and current status weight } \\
\hline Prior status weight $(\mathrm{p})$ & $\begin{array}{c}0.296^{+} \\
(0.070)\end{array}$ & $\begin{array}{c}0.305^{\dagger} \\
(0.068)\end{array}$ & $\begin{array}{c}0.187^{*} \\
(0.107)\end{array}$ & $\begin{array}{c}0.162 \\
(0.137)\end{array}$ & $\begin{array}{c}0.306^{\dagger} \\
(0.095)\end{array}$ & $\begin{array}{c}0.138 \\
(0.138)\end{array}$ \\
\hline $\mathrm{p} *$ female & & & & & $\begin{array}{c}-0.021 \\
(0.132)\end{array}$ & \\
\hline Current status weight (r) & $\begin{array}{c}0.704^{\dagger} \\
(0.070)\end{array}$ & $\begin{array}{r}0.695^{\dagger} \\
(0.068)\end{array}$ & $\begin{array}{c}0.813^{\dagger} \\
(0.107)\end{array}$ & $\begin{array}{c}0.838^{\dagger} \\
(0.137)\end{array}$ & $\begin{array}{c}0.694^{\dagger} \\
(0.095)\end{array}$ & $\begin{array}{r}0.862^{+} \\
(0.138)\end{array}$ \\
\hline$r *$ female & & & & & $\begin{array}{c}0.021 \\
(0.132)\end{array}$ & \\
\hline \multicolumn{7}{|l|}{ Social Status } \\
\hline Lower status & $\begin{array}{r}-0.282^{\dagger} \\
(0.043)\end{array}$ & $\begin{array}{r}-0.272^{\dagger} \\
(0.043)\end{array}$ & $\begin{array}{r}-0.285^{\dagger} \\
(0.042)\end{array}$ & $\begin{array}{r}-0.285^{\dagger} \\
(0.044)\end{array}$ & $\begin{array}{r}-0.283^{\dagger} \\
(0.044)\end{array}$ & $\begin{array}{c}-0.287 \\
(0.041)\end{array}$ \\
\hline Lower-middle status & $\begin{array}{r}-0.154^{\dagger} \\
(0.041)\end{array}$ & $\begin{array}{r}-0.170^{\dagger} \\
(0.042)\end{array}$ & $\begin{array}{r}-0.169^{\dagger} \\
(0.039)\end{array}$ & $\begin{array}{r}-0.174^{\dagger} \\
(0.039)\end{array}$ & $\begin{array}{c}0.154^{\dagger} \\
(0.041)\end{array}$ & $\begin{array}{r}-0.174^{\dagger} \\
(0.038)\end{array}$ \\
\hline Higher-middle status & $\begin{array}{r}-0.077^{\dagger} \\
(0.036)\end{array}$ & $\begin{array}{r}-0.083^{\dagger} \\
(0.037)\end{array}$ & $\begin{array}{r}-0.072^{\dagger} \\
(0.035)\end{array}$ & $\begin{array}{r}-0.073^{*} \\
(0.038)\end{array}$ & $\begin{array}{r}-0.077^{\dagger} \\
(0.036)\end{array}$ & $\begin{array}{r}-0.075^{\dagger} \\
(0.035)\end{array}$ \\
\hline Higher status & $\begin{array}{c}0.513^{\dagger} \\
(0.039)\end{array}$ & $\begin{array}{r}0.525^{\dagger} \\
(0.039)\end{array}$ & $\begin{array}{r}0.526^{\dagger} \\
(0.039)\end{array}$ & $\begin{array}{r}0.532^{\dagger} \\
(0.040)\end{array}$ & $\begin{array}{r}0.513^{\dagger} \\
(0.039)\end{array}$ & $\begin{array}{r}0.536^{+} \\
(0.044)\end{array}$ \\
\hline \multicolumn{7}{|l|}{ Mobility variables } \\
\hline Mobility & & $\begin{array}{r}0.075^{\dagger} \\
(0.037)\end{array}$ & & & & \\
\hline Upward mobility & & & $\begin{array}{c}0.003 \\
(0.064)\end{array}$ & & & \\
\hline Downward mobility & & & $\begin{array}{c}0.137^{\dagger} \\
(0.055)\end{array}$ & & & \\
\hline One-step upward mobility (1 = yes) & & & & $\begin{array}{c}0.011 \\
(0.080)\end{array}$ & & \\
\hline Two-step upward mobility ( 1 = yes) & & & & $\begin{array}{c}-0.002 \\
(0.093)\end{array}$ & & \\
\hline Three-step upward mobility ( 1 = yes) & & & & $\begin{array}{c}-0.090 \\
(0.153)\end{array}$ & & \\
\hline One-step down. mobility $(1=$ yes $)$ & & & & $\begin{array}{r}0.147^{\dagger} \\
(0.059)\end{array}$ & & \\
\hline Two-step down. mobility (1 = yes) & & & & $\begin{array}{c}0.169 \\
(0.117)\end{array}$ & & \\
\hline Three-step down. mobility $(1=$ yes $)$ & & & & $\begin{array}{c}0.063 \\
(0.233)\end{array}$ & & \\
\hline Upward mobility to the highest rank & & & & & & $\begin{array}{c}-0.054 \\
(0.123)\end{array}$ \\
\hline Upward mobility not to highest rank & & & & & & $\begin{array}{c}0.010 \\
(0.066)\end{array}$ \\
\hline $\mathrm{N}$ & 16,936 & 16,936 & 16,936 & 16,936 & 16,936 & 16,936 \\
\hline
\end{tabular}

Robust standard errors in parentheses. ${ }^{*} \mathrm{p}<0.05,{ }^{\dagger} \mathrm{p}<0.01$. 
mobility because of the large number of upwardly mobile people from lower social statuses. It is likely that their absolute social statuses did not change, or even improved, but their relative status lowered because many new immigrants made a fortune in the cities.

We next explore the sex disparities in the relationship between intragenerational rank mobility and happiness. Results are shown in model 5. We allow the parameters that weight the relative importance of prior social status and current social status to vary by sex. The interaction terms show that women's happiness levels are not more significantly affected by their social origins or destinations compared with men. Thus, we find no support for hypothesis $1 \mathrm{~d}$ and hypothesis $2 \mathrm{~d}$.

In order to test hypothesis $2 a$ and hypothesis $2 b$, we break upward mobility in model 6 into two variables: upward mobility to the highest rank and upward mobility not to the highest rank. Neither of them is significant. This means that even people upwardly mobile to the highest rank are not significantly happier. It supports our hypothesis $2 b$.

The performance of control variables is generally consistent across models. Being ethnic Han is not significant. However, age, female, communist party member, Han ethnicity, married, and time at destination are all shown to have significant relationships with individuals' happiness. As age advances, happiness follows a u-shaped pattern. Females, communist party members, married people, and those with longer time at social destination are happier than others. Although in some models being rural is not significant, rural residents seem to be happier than urban residents in general. The complete table with coefficients of control variables can be found in the online supplement.

We then test the same hypotheses on intergenerational mobility in Table 5. Model 1 shows that the relative weight of one's current status is 0.765 versus 0.235 for father's status. Being intergenerationally mobile, irrespective of whether it is downward or upward mobility, is not significant in model 2. Although the sign becomes negative, the magnitude is small and there is no support for hypothesis 1a. Distinguishing between upward and downward in model 3 shows that neither of them is significant, although they are both negative. This implies no support for hypothesis $1 \mathrm{~b}$. After adding variables indicating social mobility distance in model 4 , similarly, no mobility variables indicating mobility distance are significant. These results do not support either hypothesis 1c or hypothesis 2c. Results in model 5 for sex disparities and for mobility to the highest rank in model 6 are not significant either. Thus, no evidence is found to support hypothesis $1 \mathrm{~d}$, hypothesis $2 \mathrm{~d}$, or hypothesis 2a. Upwardly mobile people are not found to be significantly happier, which supports our hypothesis $2 \mathrm{~b}$. The performances of control variables are similar to those in the intragenerational mobility models. The findings of social status and intergenerational social mobility together suggest that more happiness is mostly generated by higher relative status itself, especially the social destination, while there is no relation with intergenerational social mobility.

Findings from intra- and intergenerational mobility do not provide evidence for most of our hypotheses except hypothesis $2 b$. In general, our findings favor the social comparison explanations over the social adaptation explanations. Higher social status itself generates higher levels of happiness. Mobile individuals are more 
Table 5: Intergenerational estimates from diagonal mobility models predicting happiness.

\begin{tabular}{|c|c|c|c|c|c|c|}
\hline & Model 1 & Model 2 & Model 3 & Model 4 & Model 5 & Model 6 \\
\hline \multicolumn{7}{|l|}{ Father's and current status weight } \\
\hline Father's status weight $(\mathrm{p})$ & $\begin{array}{c}0.235^{\dagger} \\
(0.050)\end{array}$ & $\begin{array}{c}0.235^{\dagger} \\
(0.050)\end{array}$ & $\begin{array}{c}0.230^{\dagger} \\
(0.090)\end{array}$ & $\begin{array}{c}0.187 \\
(0.158)\end{array}$ & $\begin{array}{c}0.173^{\dagger} \\
(0.066)\end{array}$ & $\begin{array}{c}0.324^{+} \\
(0.145)\end{array}$ \\
\hline $\mathrm{p} *$ female & & & & & $\begin{array}{c}0.128 \\
(0.086)\end{array}$ & \\
\hline Current status weight (r) & $\begin{array}{c}0.765^{\dagger} \\
(0.050)\end{array}$ & $\begin{array}{c}0.765^{\dagger} \\
(0.050)\end{array}$ & $\begin{array}{c}0.770^{\dagger} \\
(0.090)\end{array}$ & $\begin{array}{c}0.813^{\dagger} \\
(0.158)\end{array}$ & $\begin{array}{r}0.827^{\dagger} \\
(0.066)\end{array}$ & $\begin{array}{r}0.676^{+} \\
(0.145)\end{array}$ \\
\hline$r *$ female & & & & & $\begin{array}{c}-0.128 \\
(0.086)\end{array}$ & \\
\hline \multicolumn{7}{|l|}{ Social Status } \\
\hline Lower status & $\begin{array}{r}-0.294^{\dagger} \\
(0.041)\end{array}$ & $\begin{array}{r}-0.297^{\dagger} \\
(0.042)\end{array}$ & $\begin{array}{r}-0.297^{\dagger} \\
(0.042)\end{array}$ & $\begin{array}{r}-0.310^{\dagger} \\
(0.044)\end{array}$ & $\begin{array}{r}-0.294^{\dagger} \\
(0.041)\end{array}$ & $\begin{array}{r}-0.306^{\dagger} \\
(0.045)\end{array}$ \\
\hline Lower-middle status & $\begin{array}{r}-0.164^{\dagger} \\
(0.043)\end{array}$ & $\begin{array}{r}-0.162^{\dagger} \\
(0.045)\end{array}$ & $\begin{array}{r}-0.162^{\dagger} \\
(0.045)\end{array}$ & $\begin{array}{r}-0.165^{\dagger} \\
(0.050)\end{array}$ & $\begin{array}{r}-0.164^{\dagger} \\
(0.043)\end{array}$ & $\begin{array}{r}0.139^{\dagger} \\
(0.059)\end{array}$ \\
\hline Higher-middle status & $\begin{array}{r}-0.087^{\dagger} \\
(0.038)\end{array}$ & $\begin{array}{r}-0.086^{\dagger} \\
(0.038)\end{array}$ & $\begin{array}{r}-0.086^{\dagger} \\
(0.040)\end{array}$ & $\begin{array}{c}-0.045 \\
(0.051)\end{array}$ & $\begin{array}{r}-0.085^{\dagger} \\
(0.039)\end{array}$ & $\begin{array}{c}-0.066 \\
(0.044)\end{array}$ \\
\hline Higher status & $\begin{array}{r}0.545^{\dagger} \\
(0.042)\end{array}$ & $\begin{array}{r}0.545^{\dagger} \\
(0.042)\end{array}$ & $\begin{array}{r}0.544^{\dagger} \\
(0.043)\end{array}$ & $\begin{array}{c}0.522^{\dagger} \\
(0.045)\end{array}$ & $\begin{array}{r}0.543^{+} \\
(0.042)\end{array}$ & $\begin{array}{c}0.511^{\dagger} \\
(0.058)\end{array}$ \\
\hline \multicolumn{7}{|l|}{ Mobility variables } \\
\hline Mobility & & $\begin{array}{c}0.009 \\
(0.042)\end{array}$ & & & & \\
\hline Upward mobility & & & $\begin{array}{c}-0.011 \\
(0.058)\end{array}$ & & & \\
\hline Downward mobility & & & $\begin{array}{c}-0.007 \\
(0.066)\end{array}$ & & & \\
\hline One-step upward mobility ( 1 = yes) & & & & $\begin{array}{c}-0.010 \\
(0.070)\end{array}$ & & \\
\hline Two-step upward mobility ( 1 = yes) & & & & $\begin{array}{c}-0.094 \\
(0.098)\end{array}$ & & \\
\hline Three-step upward mobility $(1=$ yes $)$ & & & & $\begin{array}{c}0.009 \\
(0.144)\end{array}$ & & \\
\hline One-step down. mobility $(1=$ yes $)$ & & & & $\begin{array}{c}-0.036 \\
(0.079)\end{array}$ & & \\
\hline Two-step down. mobility $(1=$ yes $)$ & & & & $\begin{array}{c}0.062 \\
(0.138)\end{array}$ & & \\
\hline Three-step down. mobility $(1=$ yes $)$ & & & & $\begin{array}{c}0.075 \\
(0.161)\end{array}$ & & \\
\hline Upward mobility to the highest rank & & & & & & $\begin{array}{c}0.090 \\
(0.132)\end{array}$ \\
\hline Upward mobility not to highest rank & & & & & & $\begin{array}{c}-0.057 \\
(0.061)\end{array}$ \\
\hline $\mathrm{N}$ & 16,936 & 16,936 & 16,936 & 16,936 & 16,936 & 16,936 \\
\hline
\end{tabular}

Robust standard errors in parentheses. ${ }^{*} \mathrm{p}<0.05,{ }^{\dagger} \mathrm{p}<0.01$. 
likely to look beyond their social origins for a reference group, and upward mobility to the highest rank doesn't necessarily mean being happier. In fact, our findings on "satisfied losers" suggest that those people who had short-distance, downward intragenerational mobility may have compared themselves with others in their social destination. Comparing with stable members at their social destination, who had lower status than them before, may still make them feel superior. Similar with the findings in Graham and Pettinato (2002) in Peru, the absolute coefficient of mobility on happiness seems to be larger for people in the middle of the distribution than for either the very wealthy or the very poor.

Beyond social comparison explanations, there are several possible additional explanations for "satisfied losers." These include voluntary downward mobility and behavioral traits. However, these explanations are less plausible. Voluntary downward mobility happens more often among older people and females, but our regression results show that males and young people are more likely to have experienced short-distance downward mobility. If our "satisfied losers" are happier than nonsatisfied respondents by nature, it's hard to explain why only one-step downward mobility matters.

\section{Conclusion and Discussion}

The current article examines the relationship between intra- and intergenerational rank mobility and happiness in China. As early as Durkheim (1951) and Sorokin (1962), social scientists have hypothesized that social mobility might be associated with various psychological and personality disorders and dissatisfaction. But empirical evidence on this hypothesis is still rare and limited efforts mostly originate from developed countries. This article fills the gap by examining this hypothesis in a developing country's context-i.e., China. Furthermore, this article contributes to the happiness research domain by statistically disentangling the independent contributions of social origin, social destination, and mobility, whereas the lion's share of previous research rarely attempts to disentangle the contributions of mobility from social status.

Employing Chinese representative data, we find no support for any effect of the intergenerational mobility variables on happiness, net of father's and current status and controls. By contrast, intragenerational mobility, especially intragenerational one-step downward mobility has a positive association with happiness. Apparently, we have a group of satisfied losers in China. These results cannot be interpreted with ideas of social adaptation as inspired by the classical work of Durkheim and Sorokin. In our view, the idea of social comparison offers a plausible explanation for our findings. Relative social status is a strong predictor of individual happiness. Although downwardly mobile individuals have lost relative status, they tend to compare themselves more with those in their social destinations rather than those in their social origins. ${ }^{7}$ Another conclusion is that because the upwardly mobile are not less happy, we have no evidence for frustrated achievers.

Most previous studies on social mobility only considered men. The Chinese data allowed us to take women into account. Because of the communist effort to improve women's status by adopting a centralized danwei system ensuring equal 
employment opportunities for men and women, China provides a unique chance to explore the consequences of women's intragenerational mobility. Interestingly, for both intra- and intergenerational relative status mobility, women did not behave differently from men with regard to the relative impact of origin and attained status position. On average, the relative impact of status of origin was about one-fourth and three-fourths for status of destination.

However, this study is not without limitations. First of all, our data do not include enough information about recent stressors and individual's positivism, which may influence the relationship between social mobility and happiness. Second, although the social comparison explanation seems plausible, the true reference group is rarely known. Further research may reexamine this relationship using longitudinal panel data to fully understand social mobility and happiness as a dynamic process, but this kind of data is still very limited in China. To better assess how social mobility may lie at the root of any differential in happiness and mental health, we also need new data and studies that give us a better sense of the mechanisms.

Granting these limitations, however, we believe that our findings have important consequences in terms of policy. We have shown that relative social status is strongly linked with individual happiness, while upward mobility itself cannot necessarily bring people more happiness. This is an important message for policymakers in transitional societies. If happiness of the population is a serious consideration, policy makers should not only focus on economic growth but also invest more in reducing increasing levels of inequality. 


\section{Notes}

1 Tibet, Taiwan, Hong Kong, and Macau are not included.

2 Because of multiple observations at the boundaries of the quantiles, the proportions of number of observations in each class can be higher or lower than 25 percent.

3 In the 2003 and 2006 waves, father's status is measured as father's position when the respondent was age 18. In the 2008 wave, father's status is measured as father's position when the respondent was age 14 .

4 For people who have retired, time at destination is measured by the difference between the year a respondent ended his or her last job and the year the respondent started his or her last job.

5 Because one primary goal here is to assess the role of intragenerational social mobility rather than to explain happiness per se, we do not control for every possible factor that that might also have a significant association with our outcome variable. Of course, some of the association between social mobility and happiness in the model may be due to a respondent's mental health and personality, but separate analyses with the Chinese General Social Survey wave-which includes controls for mental health, personality indicators, and recent stressors-did not lead to different results.

6 The models without covariates give the same results. Concerning the space, we omit them here.

7 The estimates show that the destination weight is indeed bigger than the origin weight, but that applies to every mobile person. We tested also whether downwardly mobile respondents weighted their destination even more than the upwardly mobile. This indeed appeared to be the case, but it was not significant at $\mathrm{p}<0.05$.

\section{References}

Acock, Alan C. 2005. "Working with Missing Values." Journal of Marriage and Family 67(4): 1012-1028. http://dx.doi.org/10.1111/j.1741-3737.2005.00191.x

Becchetti, Leonardo, and Fiammetta Rossetti. 2009. “When Money Does Not Buy Happiness: The Case of 'Frustrated Achievers'." The Journal of Socio-Economics 38(1): 159-167. http: //dx.doi.org/10.1016/j.socec.2008.08.009

Bian, Yanjie, and Lulu Li. 2012. "The Chinese General Social Survey (2003-8) Sample Designs and Data Evaluation." Chinese Sociological Review 45(1): 70-97. http://dx.doi .org/10 . 2753/CSA2162-0555450104

Brockmann, Hilke, Jan Delhey, Christian Welzel, and Hao Yuan. 2009. "The China Puzzle: Falling Happiness in a Rising Economy." Journal of Happiness Studies 10(4): 387-405. http://dx.doi.org/10.1007/s10902-008-9095-4

Carlin, John B., John C. Galati, and Patrick Royston. 2008. “A New Framework for Managing and Analyzing Multiply Imputed Data in Stata." Stata Journal 8(1): 49-67.

Clark, Andrew E., and Emanuela D'Angelo. 2009. “Upward Social mobility, Wellbeing and Political Preferences: Evidence from the BHPS." Working paper, Paris School of Economics, 17 October.

De Graaf, Nan Dirk. 1991. “Distinction by Consumption in Czechoslovakia, Hungary, and the Netherlands." European Sociological Review 7(3): 267-290. 
De Graaf, Nan Dirk, Paul Nieuwbeerta, and Anthony Heath. 1995. “Class Mobility and Political Preferences: Individual and Contextual Effects." American Journal of Sociology 100(4): 997-1027. http://dx.doi.org/10.1086/230607

Diener, Ed. 1984. "Subjective well-being." Psychological Bulletin, 95(3), 542-575. http: //dx.doi.org/10.1037/0033-2909.95.3.542

Dorn, David, Justina A.V. Fischer, Gebhard Kirchgässner, and Alfonso Sousa-Poza. 2007. "Is It Culture of Democracy? The Impact of Democracy, and Culture on Happiness." Social Indicators Research 82(3): 505-526. http://dx.doi.org/10.1007/s11205-006-9048-4

Duncan, Otis Dudley. 1966. "Methodological Issues in the Analysis of Social Mobility." Pp. 51-97 in Social Structure and Mobility in Economic Development,edited by N. J. Smelser and S. M. Lipset. Chicago: Aldine.

Durkheim, Emile. 1951. Suicide: A Study in Sociology [1897]. Translated by JA Spaulding and G. Simpson. Glencoe, Illinois: The Free Press.

Erikson, Robert, John H. Goldthorpe, and Lucienne Portocarero. 1979. "Intergenerational class mobility in three Western European societies: England, France and Sweden." The British Journal of Sociology, 30(4). 415-441. http://dx . doi .org/10. 2307/589632

Ferrer-i-Carbonell, Ada. 2005. "Income and Well-being: An Empirical Analysis of the Comparison Income Effect." Journal of Public Economics 89: 997-1019. http://dx.doi. org/10.1016/j.jpubeco.2004.06.003

Festinger, Leon. 1954. "A Theory of Social Comparison Processes." Human relations 7(2): 117-140. http://dx.doi.org/10.1177/001872675400700202

Ganzeboom, Harry BG, Paul M. De Graaf, and Donald J. Treiman. 1992. “A Standard International Socio-economic Index of Occupational Status." Social Science Research 21(1): 1-56. http: //dx.doi.org/10.1016/0049-089X (92)90017-B

Graham, Carol. 2003. "Happiness and Hardship: Lessons from Panel Data on Mobility and Subjective Well-being in Peru and Russia." In DFID-ODIDPU Conference on Longitundinal Data, May, London.

Graham, Carol, and Stefano Pettinato. 2002. "Frustrated Achievers: Winners, Losers and Subjective Well-being in New Market Economies." Journal of Development Studies 38(4): 100-140. http://dx.doi.org/10.1080/00220380412331322431

Hadjar, Andreas, and Robin Samuel. 2015. "Does Upward Social Mobility Increase Life Satisfaction? A Longitudinal Analysis Using British and Swiss Panel Data." Research in Social Stratification and Mobility 39: 48-58. http://dx.doi.org/10.1016/j.rssm. 2014. 12.002

Hendrickx, John, Nan Dirk De Graaf, Jan Lammers, and Wout Ultee. 1993. “Models for Status Inconsistency and Mobility: A Comparison of the Approaches by Hope and Sobel with the Mainstream Square Additive Model." Quality and Quantity, 27(4): 335-352. http://dx.doi.org/10.1007/BF01102497

Hope, Keith. 1975. "Models of Status Inconsistency and Social Mobility Effects." American Sociological Review 40(3): 322-343. http: / /dx. doi .org/10 . 2307/2094461

Houle, Jason N. 2011. “The Psychological Impact of Intragenerational Social Class Mobility." Social Science Research 40(3): 757-772. http://dx.doi.org/10.1016/j . ssresearch. 2010.11 .008

Houle, Jason. N, and Molly A. Martin. 2011. "Does Intergenerational Mobility Shape Psychological Distress? Sorokin Revisited." Research in Social Stratification and Mobility 29(2): 193-203. http://dx.doi.org/10.1016/j.rssm.2010.11.001 
Jackson, Linda. A. 1989. "Relative Deprivation and the Gender Wage Gap." Journal of Social Issues 45(4): 117-134. http: //dx. doi .org/10.1111/j.1540-4560.1989.tb02363.x

Luttmer, Erzo FP. 2005. “Neighbors as Negatives: Relative Earnings and Well-being." The Quarterly Journal of Economics 20(3): 963-1002.

Marshall, Gordon, and David Firth. 1999. "Social Mobility and Personal Satisfaction: Evidence from Ten Countries." The British Journal of Sociology 50(1): 28-48. http: //dx.doi.org/10.1111/j.1468-4446.1999.00028.x

Newman, Katherine S. 1988. Falling from Grace: Downward Mobility in the Age of Affluence. University of California Press.

Nolen-Hoeksema, Susan. 2001. "Gender Differences in Depression." Current Directions in Psychological Science 10(5): 173-176. http://dx.doi.org/10.1111/1467-8721.00142

Ravallion, Martin, and Shaohua Chen. 2007. "China's (Uneven) Progress against Poverty." Journal of Development Economics 82(1): 1-42. http://dx.doi.org/10.1016/j . jdeveco. 2005.07 .003

Royston, Patrick. 2004. “Multiple Imputation of Missing Values." Stata Journal 4(3): 227-241.

Rubin, Donald B. 1987. Multiple Imputation for Nonresponse in Surveys. John Wiley \& Sons, Inc. http://dx.doi.org/10.1002/9780470316696

Samuel, Robin, Manfred Max Bergman, and Sandra Hupka-Brunner. 2013. "The Interplay between Educational Achievement, Occupational Success, and Well-being." Social Indicators Research 111(1): 75-96. http://dx.doi.org/10.1007/s11205-011-9984-5

Sanfey, Peter, and Utku Teksoz. 2007. “Does Transition Make You Happy?” Economics of Transition 15(4): 707-731. http://dx.doi.org/10.1111/j.1468-0351.2007.00309.x

Schreiber, Carol Tropp. 1979. Changing Places. Cambridge, MA: MIT Press.

Sobel, Michael E. 1981. “Diagonal Mobility Models: A Substantively Motivated Class of Designs for the Analysis of Mobility Effects. "American Sociological Review 46(6): 893-906. http://dx.doi.org/10.2307/2095086

Sobel, Michael E. 1985. "Social Mobility and Fertility Revisited: Some New Models for the Analysis of the Mobility Effects Hypothesis." American Sociological Review 50(5): 699-712. http://dx.doi.org/10.2307/2095383

Sorokin, Pitirim Aleksandrovič. 1962. Social and Cultural Dynamics. Transaction Publishers.

Tang, Wenfang, and William L. Parish. 2000. Chinese Urban Life under Reform: The Changing Social Contract. Cambridge University Press.

Thoits, Peggy A. 1983. "Multiple Identities and Psychological Well-being: A Reformulation and Test of the Social Isolation Hypothesis." American Sociological Review 48(2): 174-187. http://dx.doi.org/10.2307/2095103

Weakliem, David L. 1992. “Does Social Mobility Affect Political Behavior?" European Sociological Review 8(2): 153-165.

Weaver, Charles N. 1978. "Sex Differences in the Determinants of Job Satisfaction." Academy of Management Journal 21(2): 265-274. http://dx . doi .org/10.2307/255759

Wheaton, Blair. 1990. "Life Transitions, Role Histories, and Mental Health." American Sociological Review 55(2): 209-223. http: //dx.doi.org/10.2307/2095627

Xie, Yu, and Xiang Zhou. 2014. "Income Inequality in Today's China." Proceedings of the National Academy of Sciences 111(19): 6928-6933. http://dx.doi.org/10.1073/pnas . 1403158111

Zhang, Wenhong, and Lei Kaichun. 2008. "The Urban New Immigrants' Social Inclusion: Internal Structure, Present Situation and Influential Factors." Sociological Studies 5: 117141. 
Zhou, Xueguang. (2000). "Economic Transformation and Income Inequality in Urban China: Evidence from a Panel Data." American Journal of Sociology 105(4): 1135-1174. http://dx.doi.org/10.1086/210401

Acknowledgements: We thank Jason Houle, Tony Bardo, and Justin Max for their extensive comments on early versions of this work.

Emma Zang: Sanford School of Public Policy, Duke University.

E-mail: xiaolu.zang@duke.edu.

Nan Dirk de Graaf: Nuffield College, University of Oxford.

E-mail: nan.degraaf@nuffield.ox.ac.uk. 